\title{
Professor Gerald Grace's innovations in Catholic education as guide for future research
}

\author{
Jacinta Mary Adhiambo
}

\section{Introduction}

I met Professor Grace at a conference that was organized on Global Catholic Education and Integral Human Development: Setting a Social Science Research Agenda, which took place in Rome in April 2018. In this conference, Grace gave a presentation which touched me when he said that he had developed a deep interest in Catholic education and began to research and write about it. It was at this conference that I learnt about the journal of International Studies in Catholic Education. Professor Grace advanced that there were many good things happening in faith-based schools that were not known and there was a need to make people appreciate what the Catholic Church does in the field of education, especially for the poor.

Having co-edited the International Handbook of Catholic Education: Challenges for School Systems in the 21st Century and been the Executive Editor of the journal of International Studies in Catholic Education, Grace is at the forefront in the discussions on Catholic education, advancing scholarship and research. This in reality is a great contribution of Grace in the understanding of issues related to Catholic education in the 21st century. In his desire to promote readership on Catholic education, he engaged different contributors from across the world: Nigeria, Kenya, Malawi, South Africa, Belgium, Australia, United States of America, Zambia, Italy, Uruguay, United Kingdom, to mention but a few.

Going through the articles in the journal which Grace edited, one identifies the different perspectives of Catholic education across cultures and religion. That is why the journal includes articles from those who deal with other forms of faith schooling (Anglican, Jewish or Muslim) and the critics of existing forms of faith schooling. Indeed, the critics help in evaluating faith-based schooling, thus giving insights for Catholic education. The articles expose the quality touch that Grace, the Editor, gave in the selection of the themes that he sent out in the call for papers.

The innovations that this chapter endeavours to discuss emerge from selected articles edited by Grace. These include spiritual capital, contribution of different Religious Congregations that have education as a mission and

DOI: $10.4324 / 9781003171553-17$ 
understanding challenges to Catholic education in the 21st century that do need new research and scholarship. In the preface of the first issue of International Studies in Catholic Education, Grace states: 'A deeper understating of challenges facing Catholic education and of creative and progressive responses to these challenges need to be constructed from a variety of perspectives and case studies' (2009, p. 1). Indeed, there are now many case studies that have been published. This is why this chapter highlights Grace's special innovations that are posing a need to continuously engage with reading, searching and researching to keep abreast with the new approaches to understanding the concept of Catholic education. The following section reviews spiritual capital, Grace's key contribution to the understanding of Catholic education/schooling in the 21 st century.

There is a need to define what Catholic education entails: the 'formation of the human person in view of his or her final end and the good of that society to which he or she belongs and in the duties of which a person will as an adult, have a share' (Gravissimum Educationis, 1965, par. 1). The Catholic Church's view of education is to develop a person to become an active member with a transformative role in society.

\section{Grace and spiritual capital}

In his contribution towards the understanding of Catholic education, Grace (2010) articulated the element of spiritual capital for the continuity of Catholic schools. This was one of many issues that he dealt with in the discourse on Catholic education. This is why Franchi (2017) in the review of Grace's selected works identified the themes as 'mission', 'spirituality' and 'spiritual capital'; the 'preferential option for the poor'; 'faith-based schools', 'concepts of educational leadership'; 'concepts of educational "effectiveness” in Catholic schooling'; 'mission integrity', and 'Catholic values' among others. Grace argues that spiritual capital is important in a world where secularization has taken root.

In addition, he contends that spiritual capital is the inner dynamic that stems from the spiritual and religious power that give the impetus for the sense of mission, purpose and work. This is what Grace calls the sustaining and inspirational factor. This is what keeps Catholic education going given that Christian education is the mandate of the Catholic Church in obedience to the command of Jesus Christ to go and teach, baptize and spread the gospel.

At this stage, it is quite important that we discuss further the question: What is spiritual capital? There are different ways of describing or defining the concept. Moghadam and Makvandi, investigating the relationship between spiritual capital and job performance, cite Ian Marshall, who argues that spiritual capital can be measured by 'Self-awareness, vision led, positive use of adversity, compassion, holistic, diversity, independence, tendency to ask fundamental questions, spontaneity... and humility' (2019, p. 4). In the same development, Rima notes that spiritual capital is the 'Accumulated and enduring collections of belief, 
knowledge, values and dispositions that drive societal, organisational and interpersonal behaviour' (2020, p. 1).

Basing our discussion on the above description, it is clear that the intrinsic and inner power and voice that moves one to keep momentum is spiritual capital. The values of honesty, communion with our Creator-God in prayer, devotion to duty, self-sacrifice, serenity, peace, sense of responsibility, human dignity, to mention a few would be included in the list. This capital, just like material/cash capital that is invested to gain interest, should be continuously invested in Catholic education to sustain it in the future; this is likely to pose more challenges given the trend of materialism and secularism.

Spiritual capital is still timely for the current generation, which tends to look at spiritual values as outdated and may have nothing to offer in the technological era where there is a tendency to imagine that almost all the answers to problems can be obtained from the Google search engine with the click of a button. Adhiambo (2019) observes that social media challenges the Catholic schools in Kenya. Learners who are exposed to too much information in the media find a number of contradictions with the spiritual values that the Catholic schools propagate. ${ }^{1}$ Grace's idea of the inner energy that emerges from spiritual and religious beliefs needs to be perpetuated in Catholic education in the world. The question to be answered here is how will the agents of Catholic education present the spiritual capital for its continuity? May be this an invitation to researchers, Catholic education practitioners and the Catholic Church to look for new ways of evangelizing in their schools. This indeed requires new research and new scholarship on how to keep God in our schools, in ways which engage modern youth.

In the same way, Groome (2014) in analysing Catholic education in terms of 'from and for faith' argues that there are children who do not attend Catholic schools because of faith but because of the quality education offered in such schools. Such students may not be involved in the practice of faith as such. However, Groome believes that the 'Catholicism of our schools is essential if they are to both serve the common good and foster the spiritual development of students' (2014, p. 114). Indeed, the spiritual capital that Grace talked about is advanced by the above argument. Even those students whose faith is not Catholic are to be helped to connect to that inner energy. The spiritual capital developed in the graduate enables him or her to respond to social issues in the light of faith. At this point, I would like to pose a question. Is this the reality? Don't we come by some graduates who are corrupt and dishonest? Does it mean that the Catholic education did not take place? That the spiritual capital that Grace talked about is not attainable? The answer to such questions would be obtained by doing rigorous research on the impact of Catholic education and specifically spiritual capital on the lives of graduates of Catholic schools. ${ }^{2}$

It is the responsibility of each graduate of Catholic education to bloom where they are planted and to propagate the Catholic tradition and faith. However, even if the opposite is the case, there is no need to panic. Even one candle lit in 
the darkest corner of the room brightens the room. Taking the current situation of the Covid-19 pandemic, where all the learning institutions were challenged to close down and at the time of writing reopening was being discussed, that inner energy that inspires good deeds moves students of Catholic schools to be kind, loving, caring and mindful of the needs of neighbours amidst the social distancing applied as a measure to prevent infection. The "new normal" requires true rethinking of scholarship on spiritual capital when some people's faith has been tested. Will the students who have been traumatized and others who have lost their loved ones not challenge the relevance of spiritual energy in the post-Covid-19 era?

In the discussion on the goals of education, Arrupe posits that the purpose of Catholic schools 'is not to produce pious faithful allergic to the world in which they live but incapable of responding to it sympathetically but form people who are balanced, serene, constant, open to whatever is human' (as cited by Meyo, 2014, p. 130). ${ }^{3}$ This is the spiritual capital that Grace writes about - the intrinsic spiritual energy that propels one to express values of honesty, service, openness and sensitivity to what is happening now and in the future. That is why Catholic education is anchored in the Catholic traditions based on gospel values of love, mercy, forgiveness and care for each other, self-giving and sacrifice among others. In fact, Grace advances that 'education does not only refer to classroom teaching and vocational training but to the complete formation of the person' (2013, p. 105). For Grace, Catholic education is geared to the formation of people equipped with knowledge and skills to serve the common good motivated by faith and a Catholic social conscience to challenge the status quo and consistently be the voice of reason and of faiths.

The argument is not different to that in the foreword of Policy Document for Catholic Education in Kenya of 2013:

Catholic Schools are places where self confidence and trust are promoted and moral, spiritual and intellectual potential realized for the integral development of each person... schools as places of evangelization, socialization and places where children are helped to internalize and live the Gospel values and positive traditional values.

(Kenya Conference of Catholic Bishops, 2013, p. 5)

From the foregoing presentation I am still of the opinion that the discourse on spiritual capital needs to be expounded by scholars to propagate its relevance in the 21st century. The topic cannot be exhausted and Grace's legacy in this area will live on and that is one way his contribution in the field can be celebrated. A review of Grace's book on Faith, Mission and Challenge in Catholic Education engages readers time and again. Franchi (2017) posits that Grace challenges those who have the mission of formal education and those interested in Catholic Education Studies to gauge how they practise and dedicate themselves to faith and mission in the provision of Catholic education today. 


\section{Contributions of the Religious Congregation in Catholic education from selected works of Grace ${ }^{4}$}

Religious Congregations have been and are agents of evangelization in the Catholic Church. The charisms of Religious Congregations or institutes are for the good of the Church. Canon 577 stipulates,

In the Church there are a great many institutes of consecrated life which have different gifts according to the grace which has been given to them: they more closely follow Christ who prays, or announces the kingdom of God, or does good to the people, or lives with people in the world, yet who always does the will of the Father.

(The Code of Canon Law, 1997, Canon 143)

In the same way, Vatican II's Decree Perfectae Caritatis (on the Up-to-date Renewal of Religious Life) (1965) argues that many institutes engage in a variety of apostolic work and are endowed with gifts, which vary according to the grace given to them as expressed in I Corinthians 12:4 which explains that there are varieties of gifts but the same spirit. Of course, this stand is based on what is enshrined in Canon 794, Clause 1: 'The Church has a special duty and the right to educating, for it has a divine mission of helping all to arrive at the fullness of Christian life' (The Canon Law Society, 1997, p. 183). Again, in Gravissimum Educationis (1965), the Council 'exhorts the sons (and daughters) of the Church to assist in a spirit of generosity in the whole field of education' (1965, para. 3). This is why the Church through the different Religious Congregations continues to play a vital part in the development and extension of education where they deem it necessary.

In the volumes of the journal that Grace has edited, there are many Religious Congregations or Orders that have been made reference to in relation to their contribution to Catholic education. Scanning through some of the articles, the list includes the Society of Jesus: Jesuits (Meyo, 2014); the Marist Brothers (Green, 2014); the Salesians of St. Don Bosco (Lydon, 2009); Spiritan Missionaries (Amadi, 2016), Society of Holy Child Jesus (Aidoo, 2016); Evangelizing Sisters of Mary, Sisters of the Blessed Virgin Mary: Loreto, Sisters of St. Joseph, De La Salle Brothers, Patrician Brothers among others (Adhiambo, 2019), to mention but a few. I imagine that Grace knew well that there was no way he would contribute to the discourse on Catholic education without involving the very agents of evangelization in the Church. No wonder, he challenged the Priests, Sisters, Brothers or collaborators of the Religious Congregations or Orders to research and share perspectives and challenges to make the readership of Catholic education aware of what exactly the Religious Congregations have achieved. It is common knowledge that if nothing is written about a given area or topic, there may be no addition of knowledge and people may remain ignorant. 
Looking at Catholic education from the perspective of the Salesians, according to Lydon (2009), the Salesian educator is 'the good shepherd who knows his pupils and goes before them' (p. 48). In this case, we see the aspect of Jesus the Good Shepherd (Jn 10: 14-16) inspiring the education in Salesians' schools. The qualities of the Good Shepherd: knowing the sheep, caring for the sheep, looking for the lost sheep, leading the sheep to the greener pasture are perpetuated in the Salesian schools. This is true and just and thanks to Grace, who gave this author the opportunity to tell the world the Salesian approach to education. Lydon continues to say that for Don Bosco, the contact with the young people in the classroom and formal situation is not sufficient. This calls for the educator to develop an abiding presence with the pupils or students. The 'presence' is within and beyond the school. This is indeed a great contribution in the understanding of Catholic education from Salesians' perspectives.

Marist Brothers are also presented in the works of Grace. Green (2014) presents the life of Marists in education as the disciples of Jesus and having Mary the Mother of Jesus as their model. He posits that they set out into the 'hill Country' of the students' lives 'filled with hope and joy bringing them news of justice, mercy and faithfulness of God' (Luke: 39-56, Green, 2014, p. 151). The contribution of the Marist Brothers is a call to bring good news to the 'new normal' students at different levels. Traumatized youth due to the Covid-19 pandemic lockdown that removed them from schools, some of whom have gone through all forms of abuse: sexual, child labour, domestic violence, need the education approach of the Marist Brothers. The lessons learnt from the Marist Brothers may inspire other Catholic schools.

Many Religious Congregations with education missions provide Catholic education to the poor and needy children. Wodon (2020) observes that many of the Catholic or faith-based schools are costly to parents given that they have to pay for the tuition and other fees. Indeed, some of the schools are less affordable. But why would parents wish to take their children to schools that are based in Catholic education? Wodon reports that parents value good values instilled in the young and in some cases academic performance, teacher quality and discipline. Adhiambo (2019) argues that in Kenya, many secondary schools run by the Religious Congregations ${ }^{5}$ and by extension the Catholic Church perform better in national examinations. However, there is a need to do an assessment of the impact of such schools on society and the Church. What about the values system that the schools are best known for? Do all the graduates of such Catholic schools practise the values that they appreciated while at school? Why do we still have some cases of moral decadence in society? Such questions call for further and new research studies to gauge the impact of the Catholic education offered in such schools.

'Preferential option for the poor' is a positive feature of the Catholic schools and was also one of the themes that Grace highlighted. Aristimuno (2020) argues that there are few Catholic schools in Uruguay that take care of the less privileged. Grace's article on faith, mission and challenges in Catholic education 
puts emphasis on the preferential option for the poor. Grace has understood the Catholic social teaching principle 'Option for the poor and vulnerable'. Does this have a link with the service to the poor in Catholic schools? Of course, yes, the opportunity to have basic education that prepares one to fit into society takes care of the vulnerable children who may not be able to afford an education like that of their colleagues from rich families. Especially in the education mission of the Church, the poor are to be taken care of. At this point, the question that Wodon (2020) poses remains a key area for research: How are the poor served in the Catholic schools in other parts of Africa and other developing countries? Maybe this is the right time to obtain the stories and lived experiences of the beneficiaries of such schools and to further the discussion on Catholic education and service for the poor.

\section{Challenges facing Catholic education from selected articles}

Scanning through the articles that are in International Studies in Catholic Education, one realizes that the provision of Catholic education encounters a number of challenges. It is paramount that these are highlighted to form a basis for future discourse on how to deal with them.

To begin with, Grace (2016) reports that there are countries where Catholic schools find themselves admitting many children from 'well-to-do' families and from other faiths because of the principle of openness. This is an issue for Catholic education, which stresses that the Church also ought to offer educational services to the poor. This does not imply that the Church does not care about children from more advantaged families. They too are to be taken care of but priority is to be given to those who cannot afford education.

Some of the highlighted challenges are unique to particular regions or countries. For example, in Kenya, Akala (2007) enumerates degenerating morals due to secularization of education because of the introduction of new subjects, reluctance of the government to enact certain laws and anti-religious attitudes by other stakeholders. ${ }^{6}$ What is the case at the time of writing this chapter in 2020? Challenges seem to have taken on a different orientation and facets that call for more research on how to keep Catholic education relevant in the 21st century. In Ethiopia, Chernet (2007) observes recruitment, formation and retention of school leaders as the main drawbacks. In this case, the management of the said schools need to improve on the formation and retention of leadership to continue inspiring the governance of Catholic schools.

The Catholic Church cherishes collaboration among agents of evangelization. This is why, where it is not possible to have Religious Congregations continue with the governance of their founded Catholic schools, the leadership is handed over to dedicated lay faithful. Aristimuno (2020) posits that many Catholic schools in Uruguay are run by former lay collaborators although this poses a challenge in the continuation of the charism of the Religious Congregations just in case the lay people show lack of commitment to the original vision. Religious 
Education coordinators are also involved in the governance of some of the schools. However, noted is a 'lack of strong faith experiences' (Rymarz \& Belmonte, 2014, p. 198) in some of the coordinators. A person with such an experience may not convince the Catholic school community in matters of faith if challenged. It is therefore essential that before the Religious Education coordinators or other lay collaborators are charged with responsibility for Catholic education, they ought to be adequately prepared in matter of religious beliefs, faith and Religious Congregations' charism to ensure their continuity.

In the International Handbook of Catholic Education, Grace and O'Keefe (2007) give an overview of the Catholic schools facing challenges of the 21st century. They highlight secularization as posing a problem encountered in Catholic schools. These schools are expected to counteract it with the 'Sacred Culture'. In many places where secularization has taken root, there is always a feeling that there is no place for the Supernatural Being: God. In my opinion, this is why Grace calls on Catholic schools to be vigilant so that they are not taken hostage by secularization. This would render Catholic education irrelevant in the 21st century. The religious beliefs that are promoted in Catholic schools would not occupy any space in the minds of the young and this would compromise the education mission of the Catholic Church.

\section{Conclusion}

The contribution of Professor Gerald Grace to scholarship and research in Catholic education in the selected works shows the quality of time, energy and commitment with which Grace participated in the discourse. He made society and the Catholic Church aware of what the Church is doing in the education mission, thus continuing the teaching mission of Jesus Christ the Divine Master.

The selected areas of spiritual capital, the role of the Religious Congregations or Orders in the provision of Catholic education, and recurring challenges facing Catholic schools are still relevant topics of discussion and further research. Indeed, research in these areas will make the concept of Catholic education understood in different contexts and generate new ways of appreciating Catholic education when the values propagated in such education no longer make sense to a majority of people.

In my opinion, Grace is leaving a legacy of internationality in the understanding of the studies in Catholic education. He ensured that the contributors were sourced from different nations and states. A journey through the journal exposes insights and thoughts from the developed and developing worlds, which justifies the international nature of the journal. Grace has brought his new perspective to the discourse on Catholic education. May the ideas of Grace remain in the hearts and practice of all who hold dear Catholic education and Catholic schools. 
I suggest new researchers to develop the themes that were originally present in the studies of Catholic education over the last 25 years, in order to bring new perspectives to it, particularly in the post Covid-19 context. The current situation calls for a new look at the issues related to the development of the education mission of the Catholic Church over the next 25 years.

\section{Notes}

1 Posts that encourage hatred, the dishonesty reflected in fake news, promotion of pornographic materials, materialism and individualism to mention but a few.

2 An important discussion of this challenge has been provided by Angelina Gutierrez (2012). However, further discussion could be done in different parts of the globe in the next decade.

3 Meyo in appreciating the contribution of Fr. Pedro Aruppe gives the mode of assessing the impacts of education. One who has gone through Catholic education should be seen by the good fruits that he/she produces in the society. Education that adds value to the human person.

4 It should be noted that Gerald has always made the involvement of Religious Congregations in the Catholic education mission a central feature of all his work. This can be shown by a content analysis of the articles in ISCE which shows many contributions from Religious Congregations, female and male.

5 Institute of the Blessed Virgin Mary, Sisters of Mary, Little Sisters of Francis, Franciscan Sisters of St. Ann, De La Salle Brothers, Sisters of Mary Immaculate, Nyeri, Assumption Sisters of Nairobi, Assumption Sisters of Eldoret, Missionary Congregation of the Evangelizing Sisters of Mary, Sisters of St. Joseph, Franciscan Sisters of St. Joseph, Marist Brothers to mention but a few.

6 There are cases where some argue that non-Catholic students in Catholic schools need not be subjected to attending Eucharistic Mass, and that teaching and learning Christian Religious Education should be optional in such schools, Yet the Catholic schools' management are convinced that through such activities the youth are moulded to become better citizens with moral character.

\section{References}

Adhiambo, J. M. (2019). Catholic schools in Kenya: history, achievements and challenges. International Studies in Catholic Education, 11 (1), pp. 159-177.

Aidoo, P. (2016). The contribution of the Society of the Holy Child Jesus to Catholic Education in West Africa. International Studies in Catholic Education, 8 (1), pp. 44-60.

Akala, W. J. (2007). The challenges of curriculum in Kenya's primary and secondary education: the response of the Catholic Church. In G. R. Grace (Ed.), International Handbook of Catholic Education: Challenges for School Systems in the 21st Century (pp. 619-635). Dordrecht: Springer.

Amadi, A. (2016). The contribution of the Holy Ghost Congregation to the educational development of Nigeria: historical and contemporary reflections. International Studies in Catholic Education, 8 (1), pp. 90-101.

Aristimuno, A. (2020). Challenges for Catholic schools in contemporary Uruguay. International Studies in Catholic Education, 12 (1), pp. 51-61. 
Chernet, F. A. (2007). Catholic Education in Ethiopia: challenges and prospects. In G. Grace \&. J. O'Keefe (Eds.), International Handbook of Catholic Education: Challenges for School Systems in the 21st Century (pp. 637-650). Dordrecht: Springer.

Franchi, L. (2017). Faith, Mission and Challenges in Catholic Education: The Selected Works of Gerald Grace by Gerald Grace, Book review. International Studies in Catholic Education, 9 (2), pp. 236-239.

Grace, G. (2009). On the international study of Catholic education: why we need more systematic scholarship and research. International Studies in Catholic Education, 1 (1), pp. 6-14.

Grace, G. (2010). Renewing spiritual capital: an urgent priority for the future of Catholic education internationally. International Studies in Catholic Education, 2 (2), pp. 117-128.

Grace, G. (2013). Catholic social teaching should permeate the Catholic secondary school curriculum: An agenda for reform. International Studies in Catholic Education, 5 (1), pp. 99-109.

Grace, G. (2016). Faith, Mission and Challenge in Catholic Education (pp. 1-15). London and New York: Routledge, World Library of Educationalist Series.

Grace, G. \&. J. O'Keefe. (2007). International Handbook of Catholic Education. Dordrecht: Springer.

Gravissimum Educationis, in Abbott, W. (Ed.) (1966). The Documents of Vatican II. New York: Herder and Herder.

Green, M. (2014). New wineskins: reimaging Australia's Marists. International Studies in Catholic Education, 6 (2), pp. 148-163.

Groome, T. (2014). Catholic education: from and for faith. International Studies in Catholic Education, 6 (2), pp. 113-127.

Gutierrez, A. (2012). Does Catholic education have lasting effects on adult life? Reflections of alumni from Catholic colleges and universities in the Philippines. International Studies in Catholic Education, 4 (1), pp. 16-34.

Kenya Conference of Catholic Bishops. (2013). Policy Document for Catholic Education in Kenya, 4th edition. Nairobi: KCCB.

Lydon, J. (2009). Transmission of the charism: a major challenge for Catholic education. International Studies in Catholic Education, 1 (1), pp. 42-58.

Meyo, O. S. (2014). The educational ideas of Pedro Arrupe, SJ: a valuable resource for all Catholic educators. International Studies in Catholic Education, 6 (2), pp. 128-139.

Moghadam, K. A. \& Makvandi, R. (2019). Investigating the relationship between spiritual capital and job performance with organizational citizenship behaviors in employees (Evidence from Iran). Cognet Business and Management, 6 (1), pp. 1-15. Open Access.

Perfecta Caritas in Abbott, W. (Ed.) (1966). The Documents of Vatican II. New York: Herder and Herder.

Rima, S. (2020, May 4). What is Spiritual Capital? Retrieved from https://scmli.com/wha t-is-spiritual-capital/.

Rymarz, R. \& Belmonte, A. (2014). Some life history narratives of religious education coordinators in Catholic schools. Internatonal Studies in Catholic Education, 6 (2), pp. 191-200.

The Canon Law Society. (1997). The Code of Canon Law, New Revised English Translation. London: HarperCollins Publishers.

Wodon, Q. (2020). How well do Catholic and other faith-based schools serve the poor? A study with special Africa: Part II: learning. International Studies in Catholic Education, 12 (1), pp. 3-20. 